Taking a Knee to Take a Stand: An Analysis of The Bhagavad Gita's Application to the

\section{Take a Knee Movement}

Srikar Katta

Freshman, Mathematical Economics

America was established with the intention of creating a society in which all people could and would be treated equally and represented by everyone. While America's representative society is meant to benefit all types of people - black, white, Hindu, Jewish, gay, transgender - society and the government are not always as egalitarian as minority groups hope for, causing people to take non-electoral-based political action. In the 1960s, African Americans circumvented the use of politicians and held demonstrations to gain more equal rights. While that movement made significant advancements in the fight for racial equality, People of color continue to be oppressed; in response, these communities took action by forming movements such as Black Lives Matter." Not only have average citizens taken action, but also athletes who are seen in public arenas around the country have taken a stand - or rather taken a knee. Two years ago, San Francisco 49ers' Colin Kaepernick - now currently unsigned refused to stand up while the national anthem played as a way of raising awareness of the racial brutality that surrounds people of color and bring change.

Kaepernick's actions led to the start of the Take a Knee movement, in which athletes throughout the country have refused to stand for the national anthem until racial inequality exists no more. However, others around the country have labeled the movement as being unrighteous, including President Trump. He tweeted out, "A football game...is no place to protest," and, "Numerous players, from different teams, wanted to show their 'outrage' at something that most of them are unable to define," disclosing his distasteful opinion of the athlete's patriotic stances. ${ }^{1}$ Even though the Take a Knee movement is defending the people of color's rights that are clearly outlined in America's founding texts, people still debate the virtuousness of the athlete's actions. While there are infinite ways of defining "virtuousness," The Bhagavad Gita, a poem in which Arjuna, the most notable figure of the Pandava army, questions virtuousness, morality, and duty. In response to Arjuna, his charioteer and king of Dwaraka, Krishna, explains the ideas of dharma (a person's role in the universe), yoga (paths of actions), and the three gunas (the quality of one's character defined by their actions). Krishna's discourses to Arjuna justify the morality and righteousness behind people taking a knee to their national anthem. Even though some could argue that the athletes are not fulfilling their duty and that The Bhagavad Gita cannot justify an equal-rights movement because of its ability to justify hate crimes and war on minorities, Krishna's discourses to Arjuna prove that the Take a Knee movement exemplifies righteousness.

In The Bhagavad Gita (BG), Arjuna pronounces to Krishna, “I don't want to kill 
[my cousins] - for the kingship of the three worlds, and certainly not for the earth...Evil would still cling to us when we'd killed these men here." ${ }^{2}$ Here, Krishna and Arjuna reveal the moral conflict of the epic: how can killing one's family in order to gain back a kingdom that one does not even desire be considered ethical? That moral dilemma can be carried over to the Take a Knee movement, where many people argue against the politics of kneeling to one's national anthem: how could "disgracing" your country's flag by not standing up for it ever be seen as righteous?

In response to Arjuna's

hopelessness, Krishna unveils the true meaning of dharma as being one's sacred place in the universe. Dharma can not be simplified and translated with a one word equivalent that scholars translate it to many using "duty" or "order" to represent dharma. Dharma is a way of life, a way to organize and bring harmony to someone, therefore bringing balance to the universe. Krishna's portrayal of dharma reveals that there is a hierarchy in dharma around which peace can be found. Each person has multiple dharmas; in the athletes' lives, they have a dharma to family, a dharma to citizenship, a dharma to their roles as athletes, etc. Krishna unveils to Arjuna that the dharma of one's varna - a person's occupation with respect to his caste - must be one's most important dharma.

Furthermore, he pronounces that "for [you] the warrior, there can be found nothing greater than battle for the sake of dharma." What Krishna means here is that Arjuna, being a kshatriya (warrior) has a duty to serve in battle; however, that does not translate to Arjuna fighting to kill men belligerently. Rather, Arjuna must fight in order to follow his prescribed role in the world.

While there is no caste system in America that dictates the roles and guidelines for athletes, Krishna's message can still apply to football and basketball players. Because their role in society is to play sports for others to enjoy, that should be their most important priority. In response to the people who say that the athletes may be violating their "rights" or "responsibilities," as long as the athletes are able to prioritize their varna over their other responsibilities, they would be acting morally. And because the athletes are still fulfilling their roles as athletes, they are not violating their varnic obligation, therefore acting righteously. Dharma is a structure that allows people to organize and live their lives in a way that can benefit all of society, and therefore the universe. Each person's varna is their role in society. For Arjuna, it is the role of a warrior. For someone else, it may be the role of a merchant. For the big figures of the Take a Knee movement, it is being an athlete. By organizing their lives around their varna, Arjuna and the athletes are placing focus on their role in the universe.

While the athletes are fulfilling their roles as athletes, some may raise the point that athletes taking part in politics contradict Krishna's words: “better one's own dharma, even if ineffective, than the dharma of another, practised well! Better death in one's own dharma." ${ }^{\prime 4}$ Some may argue that the 
athletes are violating Krishna's words because they are taking on the dharma of politicians. However, because the protestors and athletes live in America, they hold the rights of every American, which include proper citizenship. This form of citizenship demands a civic duty to one's country more than allegiance to a country's laws.

According to Socrates, a person staying in a country has an obligation to good citizenship by either following the laws of the society one lives in or changing those values outside the realm of politics. In The Crito, Socrates says, "But you chose instead neither Lacedaemon nor Crete and you yourself on occasion say that they [, the Athenians,] have good laws," revealing Socrates' belief that by staying in a state and not trying to change the laws and values of that society, people implicitly accept those values. ${ }^{5}$ On the other hand, another form of civic duty is to "do whatever the city and fatherland bid, or else persuade it what the just is made by nature," illustrating Socrates' belief that civic duty also arises from properly persuading the people to change the laws to fit a different idea of justice. ${ }^{6}$ In this sense, because the athletes are persuading American society to open its eyes and see the severity of racial inequality in America, the athletes are fulfilling their civic duty. And because they are fulfilling their civic duty, they are fulfilling their dharma to civic duty and acting righteously.

The problem with discussing dharma in Western society is that people are not born into any caste or prescribed any specific role at birth; people have the free will to decide their job. Not only can people decide their occupations, but they can also choose to not have one at all, which brings up the puzzling question: how can one follow a dharma to a varna if he or she is not hired to one's occupation? How can Colin Kaepernick be fulfilling his dharma to his varna if he is not playing for a football team? Because a person's occupation is what a person devotes his or her time to, whatever anyone devotes time to becomes his or her "varna." Now, this does not simply mean that people can decide to make their varna be anything possible. A person's actions must still fulfill some role in the universe that could benefit society. The theoretical reason the caste system endured in India was that everyone's roles somehow benefited society. In this sense, Kaepernick, as long as his new varna is benefitting society, is fulfilling his dharma towards his varna.

This begs another question: "what is considered beneficial to society?" In order for actions to be considered righteous, they must follow one's dharma. These actions that define dharma are described with two ideas: samkhya and yoga. Samkhya is the coalition of prakriti (i.e. material existence of nature) and purusha (i.e. the animating spirit). Samkhya involves the interaction between the animating spirit and the physical world. This interaction includes a creature's thought and desire of nature and the material world. For Krishna, samkhya is thought related to material desires, where proper thought is the rejection of such material desires. Yoga is the practice of discipline as a means to spiritual enlightenment. Samkhya is the thought that 
allows one to practice the yoga that fulfills one's dharma.

Krishna, while describing yoga to Arjuna, says that "your authority is in action alone, and never in its fruits; motive should never be in the fruits of action," displaying Krishna's thought that people must let go of the consequences of action. ${ }^{7}$ People should act out of duty, not out of reward, which requires restraint. Basically, Arjuna's action of killing is moral because he is killing only out of dharma and not the fruits of that action, such as riches or land.

Similar to Arjuna, Colin Kaepernick acts only out of dharma. Colin Kaepernick said in an interview, "I am not looking for approval. I have to stand up for people that are oppressed. ... If they take football away, my endorsements from me, I know that I stood up for what is right." ${ }^{8}$ Here, Kaepernick pronounces that he and the other athletes are not acting for some material gain, therefore acting righteously in the yogic sense. Just as Arjuna acts on the battlefield, without the wanting of fruits from actions, Krishna dictates that all actions require discipline. In the yogic sense, people must control and reign in their desires so that they act only in ways that fulfill their dharma. Kaepernick and the other athletes are able to continue accomplishing the other duties in their life, but never do they act by thinking about the fruits of their actions - keeping endorsements and other material possessions. This is what makes their actions virtuous.

Even though the athletes' may disassociate their actions from the benefits from those actions, that does not mean all their actions are righteous; they must still fulfill a set of axioms to constitute proper yoga. One such axiom is the necessity for non-consequentialist reasoning. With respect to one's motives for actions, a person's detachment from pleasures and desires and "fruit" is exactly what proper samkhya is; this is a detachment not only from the physical but also the mental. People must think without the fruits of action in mind. While this sounds similar to acting without the fruits of action, this defines the purity in thought necessary for righteous yoga.

The second axiom of yoga requires that one must "[move] away from clinging, [and he] who has no idea of 'mine', and who has no idea of 'I'...has [come] to peace." This simply supplements the idea that people must act without hoping for the reward, or fruit, of their actions; if people remove themselves from their sense of "me" and "mine," then they are acting out of obligation to the universe and not out of personal gain. Kaepernick, representing the other athletes, also said, "To me, this is bigger than football and it would be selfish on my part to look the other way," demonstrating that he has taken the "I" out of the protest, fighting for a cause greater than himself. ${ }^{10}$

The final axiom of yoga is somewhat utilitarian. Krishna proclaims to Arjuna, "[in] observing even the simple maintenance of the world, you should act,"11 unveiling Krishna's belief that actions not defined by one's varna must benefit society in some way. Fulfillment of these three axioms of yoga - restraint, selflessness, and 
commitment to the betterment of society lead to the fulfillment of one's dharma outside of his or her varna, thus justifying one's actions. In the case of the athletes, they are not protesting because they want riches or publicity, nor are they acting out of personal gain; rather, they are acting out of their civic responsibility - their other dharma - to promote equality.

Even with the explication of BG as a means to open people's to the virtue of the Take a Knee Movement, some may try and debunk the legitimacy of BG itself, therefore requiring other texts to prove the morality of the movement. The BG can be read in ways that could justify war on minorities, because people can claim that they are acting out of dharma. If this were the case, then $\mathrm{BG}$ should most definitely not be used to defend the righteousness of a movement that fights for minority rights. However, what these people would seemed to have missed was Krishna's discourse on the three gunas: rajas (i.e. passion and action), tamas (i.e. ignorance and laziness), and sattva (i.e. joy and wisdom). These gunas describe the quality (the level of purity) of a person's action. While discussing the three gunas, Krishna reveals that sattva is the highest of the three gunas, proclaiming that "when sattva has grown strong...one enters the stainless realms of those who know the highest," 12 implying that sattvic actions lead to salvation and transcendence to Krishna.

With respect to the other gunas, Krishna uses negatively connotated words to describe them, discoursing that "rajas is pain...and the fruit of tamas is ignorance,"13 portraying his disdain for people who act with rajasic and tamasic tendencies. Krishna even goes as far as to say that "those who have tamas, go downward," 14 meaning that they will have a much harder and a more cruel afterlife. There is this idea of karma in the Western sense of the word where all actions have an equal and opposite reaction; by acting out of tamas, a person's next life will be worse than if they had acted with familiarity or knowledge. Because the athletes in the Take a Knee movement are not acting ignorantly and are not backing down until they win their battle, they are not acting out of tamas.

With respect to rajas, some might ask, "why passion and action are considered bad - why is rajas bad?" By acting with rajasic tendencies, people are acting on passion, particularly the passion for material gains, including wealth, lust, gluttony. By acting on such desires, people live hedonistic lifestyles that eventually lead to forgetting dharmas and only chasing passions. If the athletes were to only act on such impulses, then the yoga of the movement would be non-existent, and the cause would no longer have dharmic meaning.

Comparatively, Krishna says that "the ones who abide in sattva rise up," unveiling his reverence for people whose actions are sattvic and, through his depiction of the consequences of the two, implies that sattva and tamas are polar opposites. When Krishna describes sattva by comparing it to "wisdom", Krishna is saying that those with sattva are full of religious enlightenment, or followers of Krishna's values. These values include not only yoga and samkhya but also 
seeing equality everywhere, Krishna proclaiming that "one who everywhere sees equality...is thought to be the highest practitioner of yoga." ${ }^{15}$

Furthermore, Krishna, describing his omniscient and omnipresent form, says, "there is no creature, moving or unmoving, that would be without me," ${ }^{16}$ revealing that Krishna exists in all people - including minority groups. By claiming it as their dharma, people that wage war against minorities and claim are acting out of tamas. Even though Arjuna was expected to kill his cousins, he recognized their equality before acting out of dharma. People that use BG to justify such heinous crimes against humanity must realize that $\mathrm{BG}$ would never defend such actions because the practice of proper yoga and samkhya would translate to sattva and obeyal of Krishna's words, the words that said that all creatures are equal. With respect to the athletes, because they are kneeling to raise awareness to racial oppression and gain equality in America, without looking for some material gain, they are following Krishna's words and are acting with sattva.

The Bhagavad Gita, while serving as the foundation for Hindu political, philosophical, and religious thought, can still serve as a philosophy for people globally. BG's prevalence in society is dictated not by its cultural beginnings but rather its universal message. Throughout history, people have used BG as a foundation for political movements. Mahatma Gandhi acknowledged the Gita as his "spiritual dictionary" in the Indian Independence Movement, leading him to coin the term satyagraha - the search for truth - as his political epicenter. ${ }^{17}$ Gandhi's discourses and use of BG led to its ideas fusing together with other political icons, such as Martin Luther King, who used it in his Letter From Birmingham Jail, and Henry David Thoreau, who applied the BG's practices of minimalism in living his life separated from society. BG draws parallels to other political theorists, such as Kant and his idea of non-consequentialist reasoning, as well as Jeremy Bentham and utilitarian practices of doing what is socially beneficial to society. The BG's prevalence and application are ubiquitous and should therefore be considered in politics, especially when dealing with problems of race and diversity in America. With respect to the Take a Knee movement, Krishna's discourses on thought and action (samkhya and yoga, respectively), duty (dharma), and the qualities of actions (sattva, rajas, and tamas) apply directly, proving the moral virtue of the athletes' actions; while these athletes may not lead their lives with accordance to BG's principles, this movement definitely does. While some may think taking a knee is wrong, The Bhagavad Gita opens people's eyes to the righteousness of the Take a Knee movement - a movement that is opening America's eyes to problems related to racial inequality. Sometimes, it is necessary to take a knee to take a stand. 


\section{NOTES}

${ }^{1}$ Betsy Klein, "Trump Stokes Attacks on NFL Players Who Protest." CNN, last modified August 10, 2018, https://www.cnn.com/2018/08/10/politics/trump-tweets-on-nfl-protests/index.html.

${ }^{2}$ The Bhagavad Gita, Trans. Laurie Patton (New York: Penguin, 2008), 12.

${ }^{3}$ Ibid., 24.

${ }^{4}$ Ibid., 20.

${ }^{5}$ Plato, Crito, in Four Texts on Socrates (Ithaca: Cornell University Press, 1984), 112.

${ }^{6}$ Ibid., 110.

${ }^{7}$ The Bhagavad Gita, trans. Laurie Patton, 29.

${ }^{8}$ Steve Wyche, "Colin Kaepernick Explains Why He Sat during National Anthem." NFL.com, last modified August 27, 2016.

http://www.nfl.com/news/story/0ap3000000691077/article/colin-kaepernick-explains-why-he-sat-during-national-an them.

${ }^{9}$ The Bhagavad Gita, trans. Laurie Patton, 35.

${ }^{10}$ Steve Wyche, "Colin Kaepernick Explains Why He Sat during National Anthem." NFL.com, last modified August 27, 2016.

http://www.nfl.com/news/story/0ap3000000691077/article/colin-kaepernick-explains-why-he-sat-during-national-an them.

${ }^{11}$ The Bhagavad Gita, trans. Laurie Patton, 41.

${ }^{12}$ Ibid., 158.

${ }^{13}$ Ibid., 159.

${ }^{14}$ Ibid., 159-160.

${ }^{15}$ Ibid., 78.

${ }^{16}$ Ibid., 121.

${ }^{17}$ Plato, Trial and Death of Socrates, xxix. 